\title{
Global distribution of upper tropospheric formic acid from the ACE-FTS
}

\author{
G. González Abad ${ }^{1}$, P. F. Bernath ${ }^{1}$, C. D. Boone ${ }^{2}$, S. D. McLeod $^{2}$, G. L. Manney ${ }^{3,4}$, and G. C. Toon ${ }^{3}$ \\ ${ }^{1}$ Department of Chemistry, University of York, York, UK \\ ${ }^{2}$ Department of Chemistry, University of Waterloo, Waterloo, Ontario, Canada \\ ${ }^{3}$ Jet Propulsion Laboratory, California Institute of Technology, Pasadena, California, USA \\ ${ }^{4}$ New Mexico Institute of Mining and Technology, Socorro, New Mexico, USA \\ Received: 17 March 2009 - Published in Atmos. Chem. Phys. Discuss.: 20 May 2009 \\ Revised: 05 October 2009 - Accepted: 06 October 2009 - Published: 23 October 2009
}

\begin{abstract}
We present the first near global upper tropospheric distribution of formic acid ( $\mathrm{HCOOH})$ observed from space using solar occultation measurements from the Fourier transform spectrometer (FTS) on board the Atmospheric Chemistry Experiment (ACE) satellite. Using a new set of spectroscopic line parameters recently published for formic acid by Vander Auwera et al. (2007) and Perrin and Vander Auwera (2007), we have retrieved the concentrations of $\mathrm{HCOOH}$ between $5 \mathrm{~km}$ and the tropopause for ACE-FTS observations from February 2004 to September 2007. We observe a significant seasonal dependence for the $\mathrm{HCOOH}$ concentrations related to vegetation growth and biomass burning. We estimate an emission ratio of $0.0051 \pm 0.0015$ for $\mathrm{HCOOH}$ relative to $\mathrm{CO}$ for tropical South American fires using a selected set of data for September 2004. Results from the balloonborne MkIV Fourier transform spectrometer are also presented and compared with the ACE measurements.
\end{abstract}

\section{Introduction}

Formic acid is one of the more abundant organic acids in the atmosphere. As a very soluble species, formic acid is found in the atmosphere as a gas and as a solute in water droplets as well as the formate anion in aerosol particles (Talbot et al., 1988). Formic and acetic acids are responsible for most of the acidity in rain water in isolated regions. Formic acid plays an important role in controlling $\mathrm{pH}$-dependent chemical reactions in clouds (Keene and Galloway, 1986, 1988; Jacob, 1986).

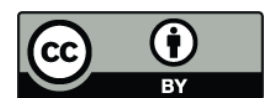

Correspondence to: G. González Abad (gga500@york.ac.uk)
Our understanding of the sources and sinks of atmospheric formic acid is still very incomplete (Khare et al., 1999), but sources include direct anthropogenic emissions (e.g. motor exhaust) (Talbot et al., 1988; Kawamura et al., 1985), soil (Sanhueza and Andreae, 1991), biomass burning emissions (Talbot et al., 1988; Coheur et al., 2007), vegetation (Jacob and Wofsy, 1988; Talbot et al., 1990; Schafer et al., 1992), isoprene oxidation (Rasmussen and Khalil, 1988; Keene and Galloway, 1986), olefin ozonolysis (Hatakeyama et al., 1981; Horie et al., 1994), aqueous phase oxidation of formaldehyde (Chameides and Davis, 1983) and gas phase reaction of $\mathrm{HCHO}$ with $\mathrm{HO}_{2}$ as well as some peroxy radical reactions (Atkinson et al., 2006; Su et al., 1979; Madronich and Calvert, 1990). The most important sinks are dry and wet deposition as well as reaction with OH (Sanhueza et al., 1996; Baboukas et al., 2000; Rinsland et al., 2004). As wet deposition is by far the most important sink, the lifetime of the $\mathrm{HCOOH}$ in the troposphere is very variable (Hartmann et al., 1991). Radojevic and Harrison (1992) estimate that the lifetime of $\mathrm{HCOOH}$ is quite short, ranging from hours to a few days. In the free troposphere, the lifetime of formic acid can be substantially longer because of the relatively slow reaction with $\mathrm{OH}$.

Formic acid has been measured in the free troposphere by in situ airborne Fourier transform infrared spectroscopy (FTIR) (Yokelson et al., 1999; Goode et al., 2000) and tunable infrared laser differential absorption spectroscopy (TILDAS) by Herndon et al. (2007) who obtained a value of about $10 \mathrm{ppbv}$ for a fire plume. Infrared solar spectra have been used in the ground-based detection of $\mathrm{HCOOH}$ by Rinsland et al. (2004) reporting concentrations between $0.31-0.80 \mathrm{ppbv}$ as well as in previous observations by Rinsland et al. (2006, 2007) and Coheur et al. (2007) using ACE satellite data. The concentrations reported in these studies

Published by Copernicus Publications on behalf of the European Geosciences Union. 


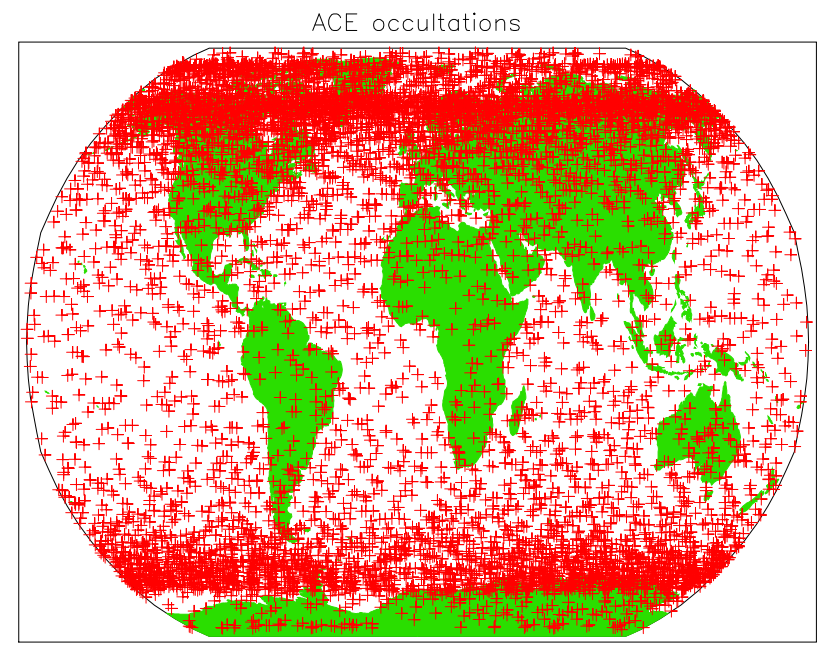

Fig. 1. Extravortex occultations for the period February 2004 to September 2007. Each red cross represents the location of an occultation.

where $3.13,0.82$ and $0.49 \mathrm{ppbv}$ for fire plumes, respectively. Remedios et al. (2007) observed the signature of $\mathrm{HCOOH}$ thermal emission using spectra from the MIPAS-B2 balloon instrument, a limb-viewing FTIR.

The first-space based observations of $\mathrm{HCOOH}$ using ACE data were published by Rinsland et al. (2006). They retrieved formic acid in biomass burning plumes and found strongly enhanced concentrations of up to $2 \mathrm{ppb}$. From 14 profiles they determined that typical background values are $0.31 \mathrm{ppb}$ in the 110-300 $\mathrm{hPa}$ range in the free troposphere for southern middle latitudes. They also calculated an emission factor for $\mathrm{HCOOH}$ at tropical middle latitudes of $1.99 \pm 1.34 \mathrm{~g} \mathrm{~kg}^{-1}$. Rinsland et al. used line parameters for the $v_{6}$ mode of formic acid as provided by HITRAN 2004 (Rothman et al., 2004). In our work, we extend the retrievals to the entire global dataset of ACE measurements using an improved set of formic acid line parameters. We also calculate the emission factor for southern tropical biomass burning plumes, and compare our results with Rinsland et al. (2006). We compare our retrievals with observations made by the MkIV balloonborne FTS.

\section{Measurements}

The Atmospheric Chemistry Experiment (ACE) is a Canadian satellite that was launched by NASA in August 2003. The primary ACE instrument is a high spectral resolution $\left(0.02 \mathrm{~cm}^{-1}\right)$ Fourier transform spectrometer (FTS) operating from 2.2 to $13.3 \mu \mathrm{m}\left(750-4400 \mathrm{~cm}^{-1}\right)$. Working primarily in solar occultation, the satellite provides altitude profile information (typically $5-100 \mathrm{~km}$ ) for temperature, pressure, and volume mixing ratios for numerous molecules of

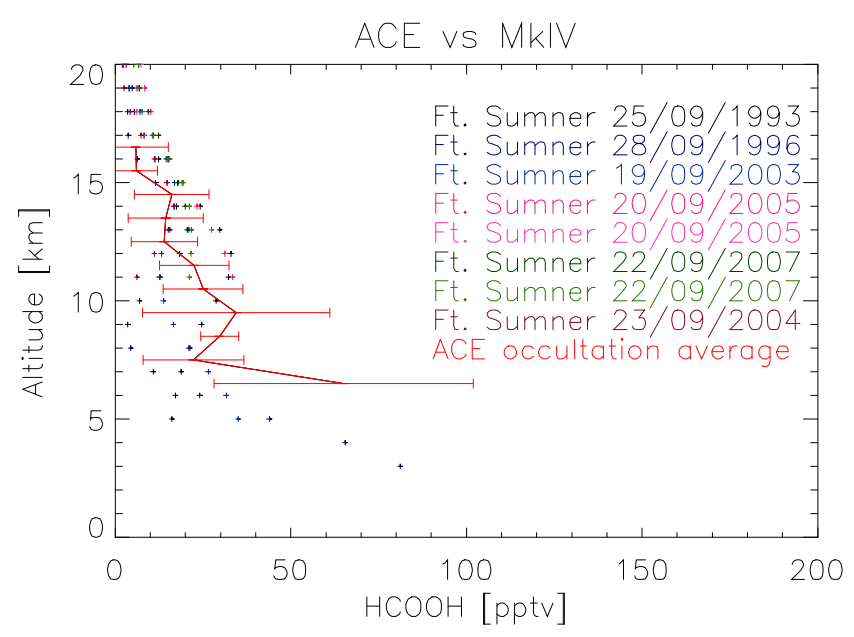

Fig. 2. Comparison of ACE data and MkIV FTS observations. The individual profiles obtained in balloon flights by MkIV fall within one standard deviation of the ACE occultation average for the same season and geographical region.

atmospheric interest between the latitudes $85^{\circ} \mathrm{N}$ and $85^{\circ} \mathrm{S}$ (Bernath et al., 2005).

The $\mathrm{HCOOH}$ retrievals reported in this paper are a research data product. Retrievals for the molecule were not available in the most recent dataset for the ACE-FTS (version 2.2). The retrieval approach used was the same global-fit least-squares approach employed for ACE-FTS version 2.2 processing (Boone et al., 2005). Version 2.2 pressures and temperatures were used in the analysis. The ACEFTS HCOOH retrievals use the Q-branch of the $v_{6}$ mode near $1105 \mathrm{~cm}^{-1}$, with a microwindow of width $10 \mathrm{~cm}^{-1}$ centered at $1105.6 \mathrm{~cm}^{-1}$. The altitude range for the retrievals extends from 5 to $20 \mathrm{~km}$. Interferers in the spectral window (retrieved simultaneously with $\mathrm{HCOOH}$ ) are $\mathrm{H}_{2} \mathrm{O}, \mathrm{H}_{2}^{18} \mathrm{O}$, $\mathrm{H}_{2}^{17} \mathrm{O}, \mathrm{HDO}, \mathrm{CO}_{2}, \mathrm{O}_{3}, \mathrm{OO}^{18} \mathrm{O}, \mathrm{O}^{18} \mathrm{OO}, \mathrm{CH}_{4}, \mathrm{CH}_{3} \mathrm{D}, \mathrm{CFC}-$ 12, HCFC-22, and HFC-134a, with separate volume mixing ratio (VMR) profiles retrieved for different isotopologues of a given molecule. Figure 7 shows an example of a spectrum calculated with the forward model, an observed ACE spectrum and the residuals for the occultation ss6168.

The spectroscopic data for $\mathrm{HCOOH}$ used in the retrievals were from Vander Auwera et al. (2007) and Perrin and Vander Auwera (2007), and have been adopted for HITRAN 2008 (Rothman et al., 2009). The new line parameters improve the quality of the retrievals, yielding smaller fitting residuals in the least-squares analysis than those achieved using the $\mathrm{HCOOH}$ spectroscopic parameters from HITRAN 2004 (Rothman et al., 2005). The line intensities changed by nearly a factor of two compared to the values given in HITRAN 2004 because Vander Auwera et al. (2007) more carefully determined the concentration of the monomer and dimer in their sample. The retrieved formic 

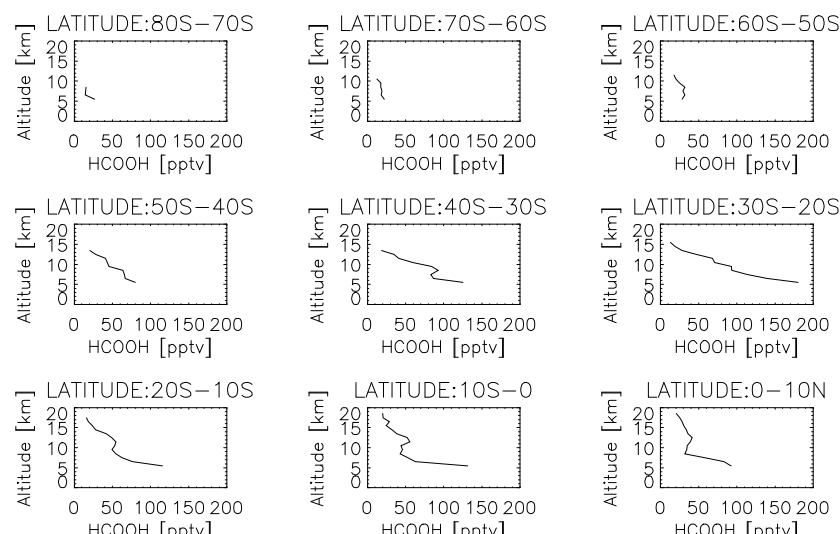

$\mathrm{HCOOH}[\mathrm{pptv}]$
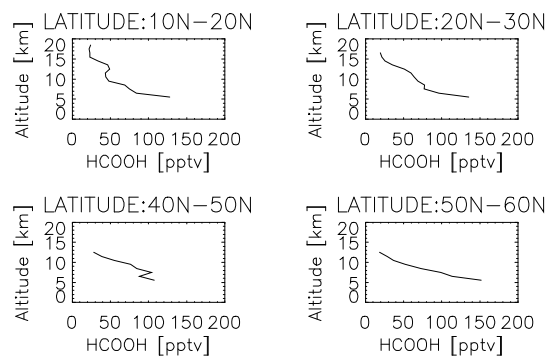

$\mathrm{HCOOH}[\mathrm{pptv}]$

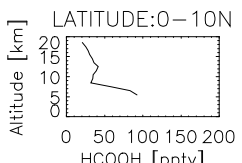

$\mathrm{HCOOH}[\mathrm{pptv}]$
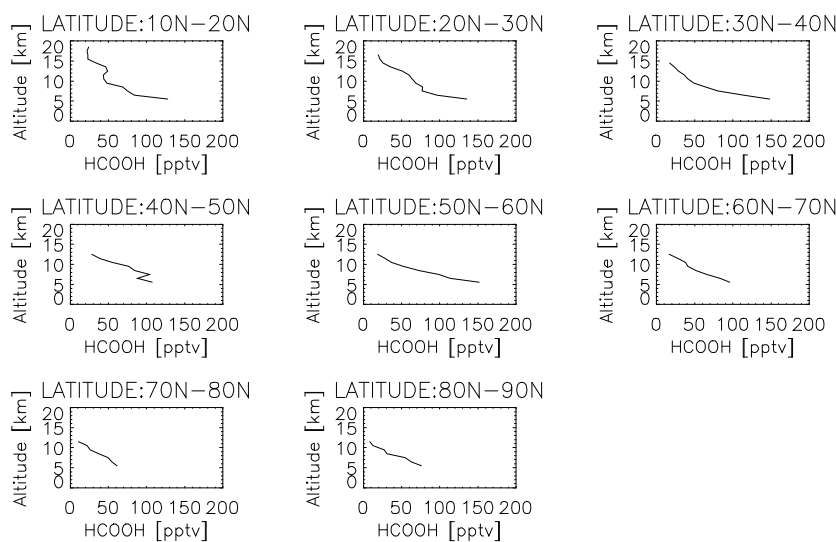

Fig. 3. Average $\mathrm{HCOOH}$ profiles for the year 2005 in 10 degree latitude bins.

acid concentrations therefore decrease by nearly a factor of two using the new line parameters. The errors in a single typical VMR profile retrieval are dominated by statistical errors, which are about $50 \%$ from $5-10 \mathrm{~km}$ in tropical regions and deteriorate at higher altitudes and towards the poles.

Almost 12000 occultations (11942) recorded between February 2004 and September 2007 have been considered in our study. They have been filtered using derived meteorological products (DMPs) (Manney et al., 2007) to remove all occultations inside or on the edge of a polar vortex. Occultations in the polar vortices have perturbed profiles because of descent by the cold, isolated air. The high inclination SCISAT orbit $\left(74^{\circ}\right.$ to the equator) (Bernath, 2006) provides a large number of occultations at high latitudes so the potentially perturbed occultations were simply discarded. The occultations were classified using potential vorticity values derived from the Met Office analyses (Swinbank and O'Neill, 1994; Swinbank et al., 2002; Davies et al., 2005) in a similar approach to that adopted by Nassar et al. (2005). The remaining 9178 extravortex occultations were filtered to remove anomalous values (e.g. large negative VMRs) and concentrations with very large estimated errors. The locations of the resulting 8125 occultations are plotted in Fig. 1.
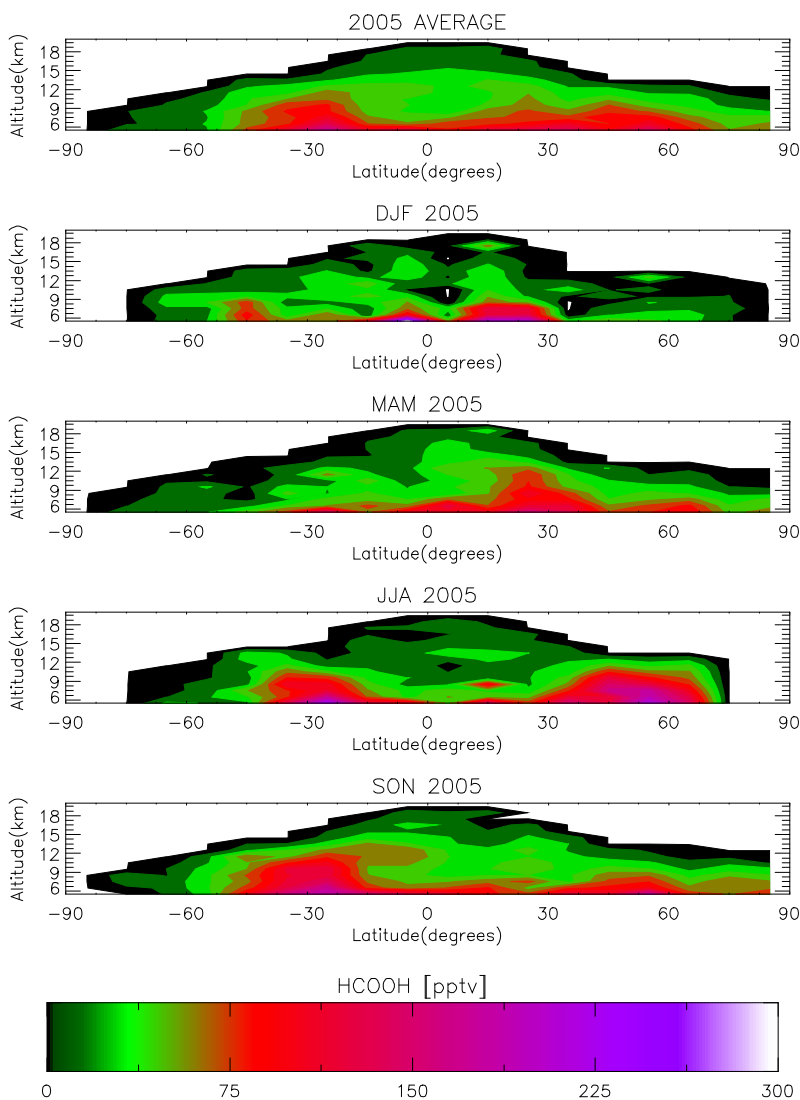

Fig. 4. Global $\mathrm{HCOOH}$ distribution for the year 2005, showing seasonal variations.

\section{Balloon comparisons}

The MkIV FTS records solar occultation spectra from a high altitude balloon in the $650-5640 \mathrm{~cm}^{-1}$ spectral range at a spectral resolution of $0.01 \mathrm{~cm}^{-1}$ (Toon, 1991). MkIV data that were obtained in eight balloon flights carried out from Ft. Sumner, New Mexico $\left(34.4^{\circ} \mathrm{N}, 104.2^{\circ} \mathrm{W}\right.$ ) have been used to compare with the ACE-FTS retrievals. These flights were during the autumn turn-around period when the stratospheric float winds are light enough to permit long durations $(15-30 \mathrm{~h})$ at float. The retrieved VMR profiles extend from the cloud tops to the float altitude $(\sim 38 \mathrm{~km})$ at $2-3 \mathrm{~km}$ vertical resolution. The MkIV retrieval uses the JPL-developed GFIT algorithm as described by Sen et al. (1998). The MkIV analysis used the same $\mathrm{HCOOH}$ absorption feature (at $1107 \mathrm{~cm}^{-1}$ ) as ACE, but with a slightly narrower window $\left(7 \mathrm{~cm}^{-1}\right.$ wide). The spectroscopic parameters used in MkIV retrievals are the same parameters that were used for ACE retrievals from Vander Auwera et al. (2007) and Perrin and Vander Auwera (2007). In Fig. 2 these data are plotted along with the ACE-FTS average profile for the September, October, November season for $30^{\circ} \mathrm{N}-54^{\circ} \mathrm{N}$ and $85^{\circ} \mathrm{W}-115^{\circ} \mathrm{W}$ (continental USA). The eight MkIV flights were made in 

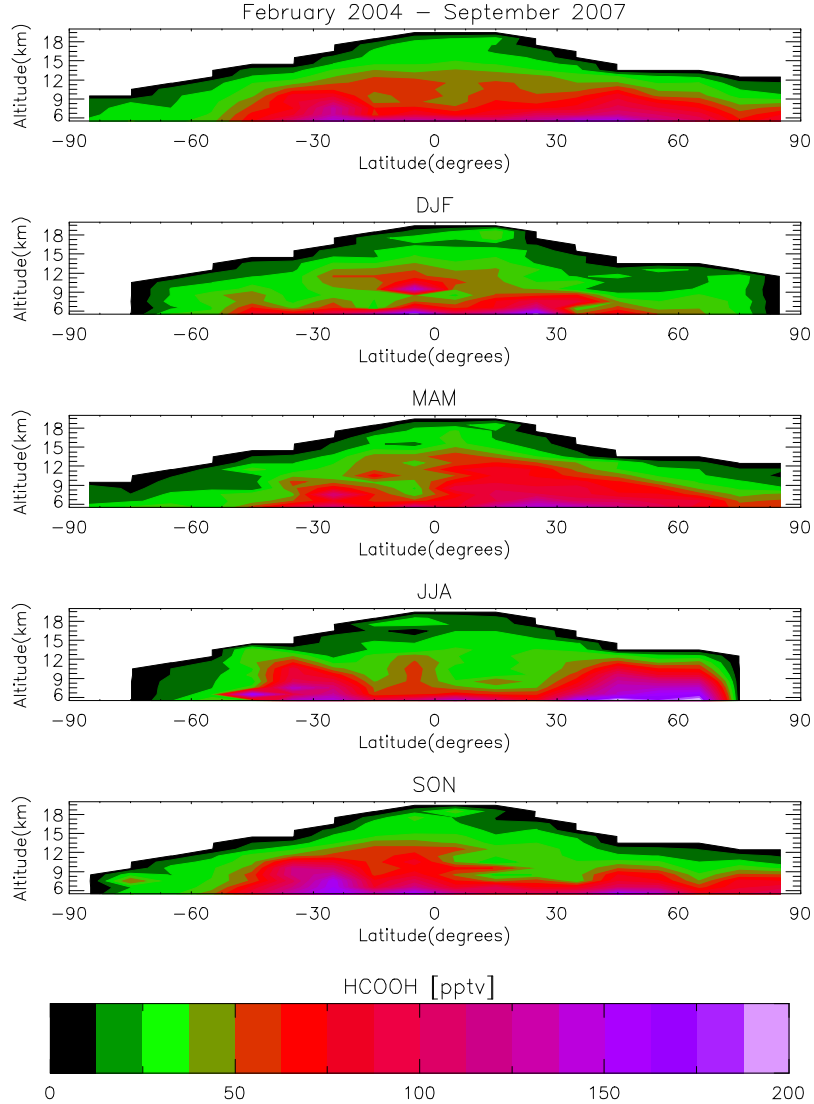

Fig. 5. Global HCOOH distribution for the period February 2004 to September 2007.
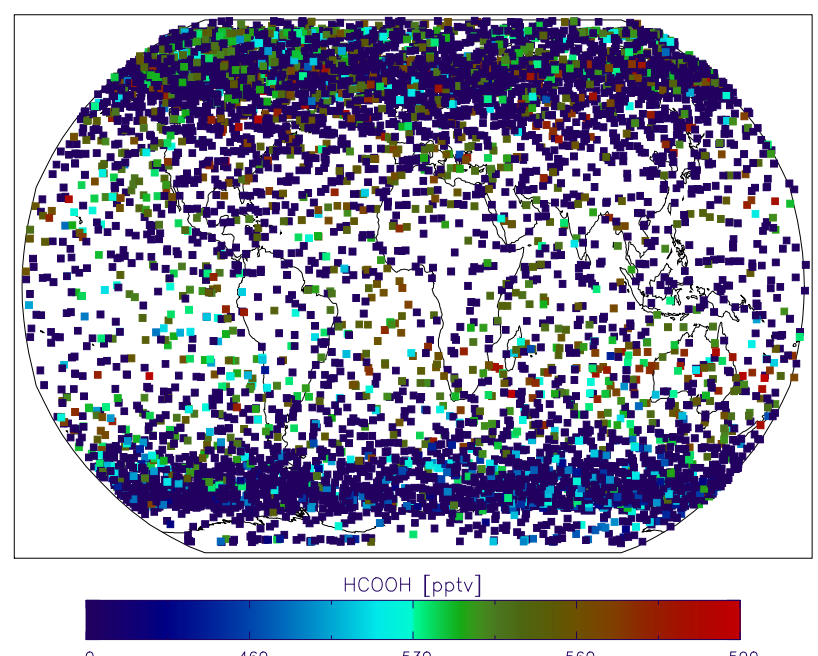

Fig. 6. HCOOH concentrations at $6.5 \mathrm{~km}$ altitude. Hot spots are likely associated with fire plumes.
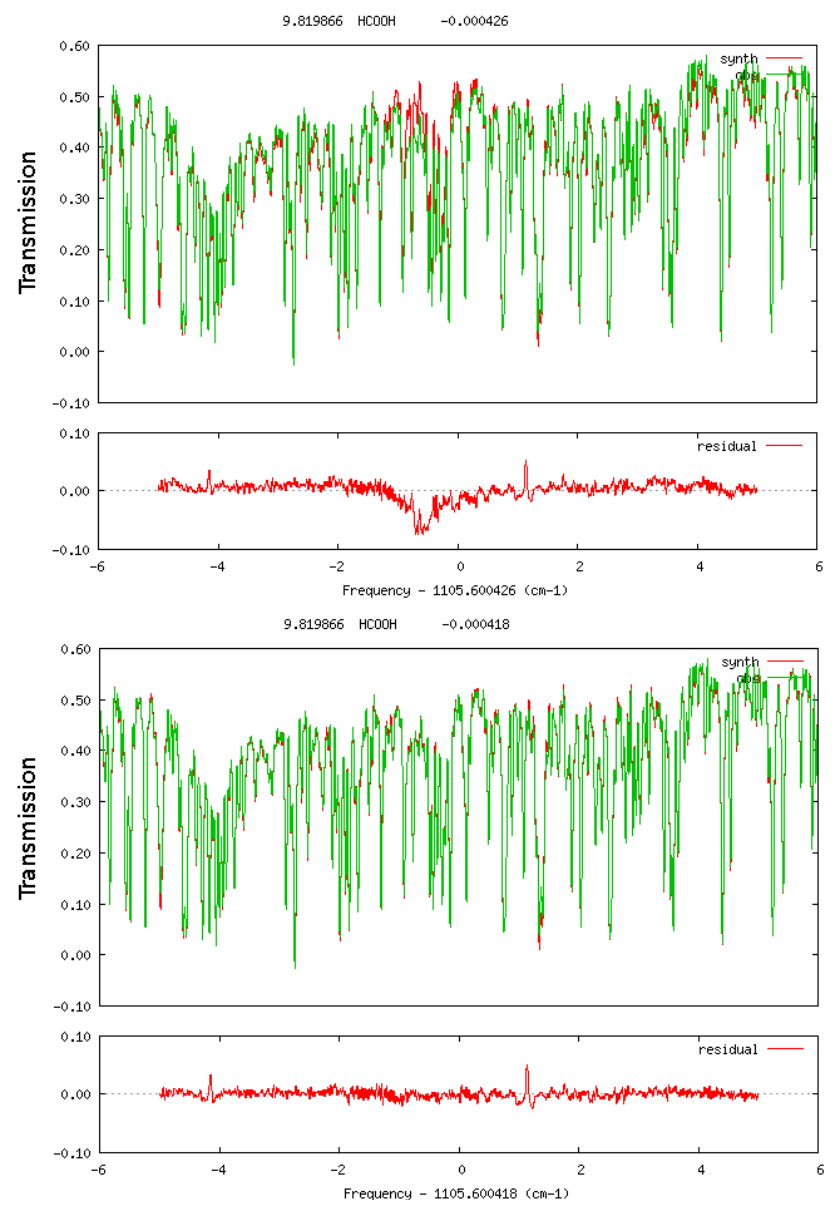

Fig. 7. Calculated spectrum, observed spectrum and residuals for occultation ss6168 at $9.81 \mathrm{~km}$. Top spectrum has no $\mathrm{HCOOH}$ in the calculated spectrum.

September from 1993 to 2007. Very few ACE occultations are near New Mexico so we compare the average ACE profile from the continental USA in the fall season with retrievals from the MkIV flights (Fig. 2). One of the 18 ACE occultations showed enhanced formic acid presumably because of a biomass burning plume and it was excluded from the average. The agreement between ACE average and MkIV profiles was within one standard deviation (Fig. 2).

\section{Global distributions, vertical profiles and emission factor}

The ACE profiles were averaged in $10^{\circ}$ latitude bins for 2005 and for the February 2004 to September 2007 time periods. The averages for 2005 are displayed in Fig. 3 and the numerical values are available in supplementary Tables 1 and 2. Global tropospheric $\mathrm{HCOOH}$ distributions observed from space are shown in Figs. 4 and 5. The data are split into four seasons, SON (September, October, November), DJF 


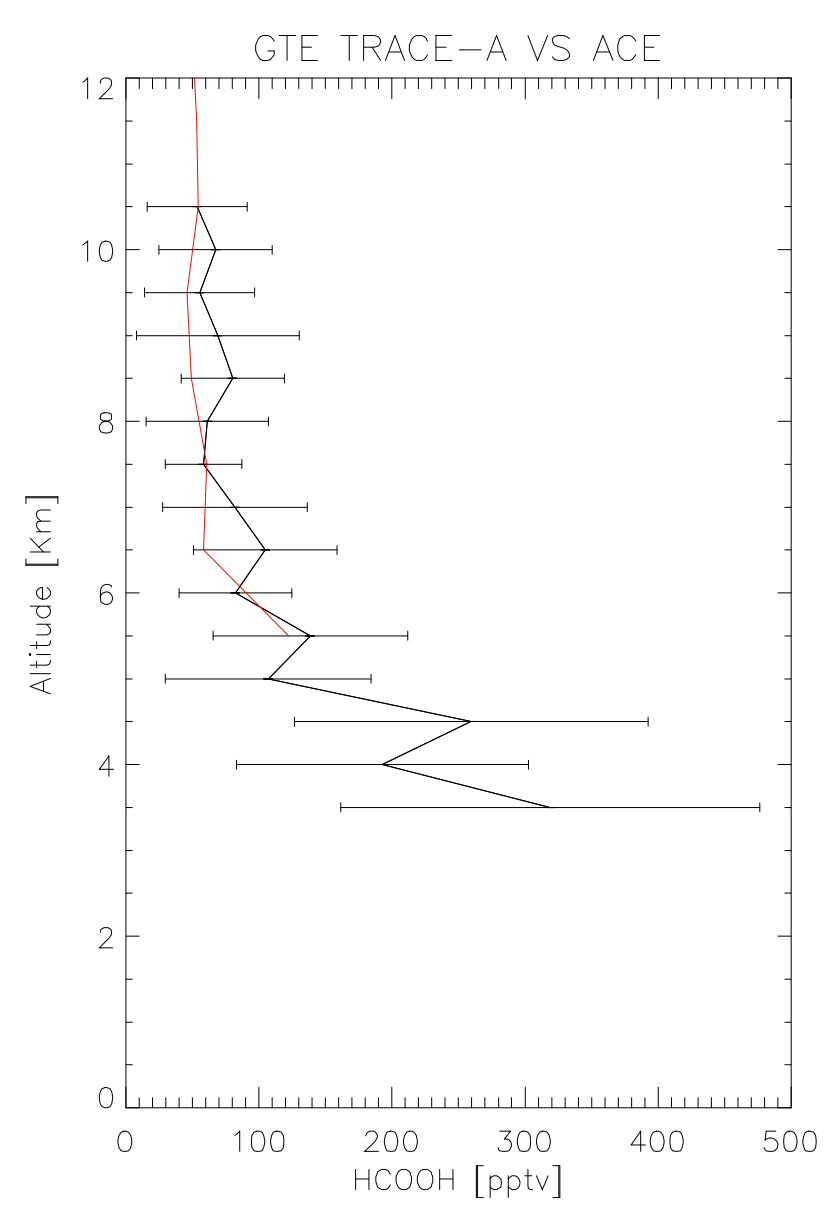

Fig. 8. GTE TRACE-A experiment compared with ACE data. In red is the $\mathrm{HCOOH}$ profile from $\mathrm{ACE}$ for the $5-15^{\circ} \mathrm{S}$ latitude bin. In black is a $\mathrm{HCOOH}$ median profile for the TRACE-A campaign of the Global Tropospheric Experiment, and one standard deviation is shown with error bars. The ACE profile falls within one standard deviation of the median GTE TRACE-A profile.

(December, January, February), MAM (March, April, May) and JJA (June, July, August). Average concentrations for 2005 and for the period February 2004-September 2007 are presented in Figs. 4 and 5, with numerical values in Tables 1 and 2. In these plots the seasonal variations are easy to see. Enhancements of $\mathrm{HCOOH}$ concentrations are observed at southern tropical latitudes for the SON biomass burning season and the MAM growing season in the Northern Hemisphere. High values are also seen in JJA in the Northern Hemisphere, perhaps associated with boreal fires as well as plant growth. On average the enhanced values are about 300 pptv.

The average formic acid profiles (Figs. 2-5) are generally consistent with the very few published aircraft profiles of formic acid. For example, average aircraft profiles from various locations are displayed in the modelling paper by Ito et al. (2007). These profiles where obtained as part of the GTE
(Global Tropospheric Experiment) (Fishman et al. 1996, Talbot et al., 1996). In Fig. 8a median profile obtained from the TRACE-A campaign data together with an appropriate ACE profile is presented. The good agreement between the ACE data and the data obtained in the TRACE-A experiment is evident. $\mathrm{HCOOH}$ concentrations are higher at lower altitudes and often show a sharp decrease with altitude near our lowest measured altitudes of 5-7 km, particularly in tropical regions. These trends at lower altitudes agree with previous studies by Andreae et al. (1988) and Talbot et al. (1992) who reported values in the boundary layer between 0.16 and $2.19 \mathrm{ppbv}$ in tropical regions. Another interesting feature is the observation of a background level of about 10 pptv at high latitudes at $5 \mathrm{~km}$ altitude. Figure 6 illustrates this more clearly by showing all observed values at $6.5 \mathrm{~km}$ in altitude. A few hot spots with concentrations of up to 590 pptv are present and are likely associated with fire plumes.

We calculate an $\mathrm{HCOOH} / \mathrm{CO}$ emission ratio for 2004 tropical South American fires following the approach of Yokelson et al. (1999) and Rinsland et al. (2006). A suitable sample of 14 occultations was used to calculate the background levels of formic acid and carbon monoxide. Using two occultations ( $\mathrm{sr6539}$ at $28^{\circ} \mathrm{S}, 165^{\circ} \mathrm{E}$ and sr6582 at $39^{\circ} \mathrm{S}, 169^{\circ} \mathrm{W}$ ) clearly associated with fires plumes we obtain an emission VMR ratio of $0.0051 \pm 0.0015$. The high concentrations of $\mathrm{CO}, \mathrm{HCN}$ and $\mathrm{C}_{2} \mathrm{H}_{6}$ in these occultations indicate that the enhanced values are due to biomass burning. Figure 9 shows the profiles of these three species in the two occultations.

Our value of $0.0051 \pm 0.0015$ is consistent with the value of $0.0114 \pm 0.0076$ obtained by Rinsland et al. (2006), when changes to the line parameters are taken into account. Concentrations as high as 0.843 ppbv were reported by Rinsland et al. (2007) for plumes detected in boreal regions. We have used occultation ss5129 to compare the values obtained by Rinsland et al. (2006) with our new retrievals. Rinsland et al. (2006) obtained a peak concentration of $0.844 \mathrm{ppbv}$ and our new peak value is $0.355 \mathrm{ppbv}$. As expected from the change in line intensities, our result is about a factor of two lower.

We have also calculated tracer-tracer correlations between the concentrations of $\mathrm{HCOOH}$ and $\mathrm{CO}, \mathrm{HCN}, \mathrm{C}_{2} \mathrm{H}_{2}, \mathrm{C}_{2} \mathrm{H}_{6}$ and $\mathrm{SF}_{6}$ for occultations associated with biomass burning plumes. High correlation coefficients with $\mathrm{CO}, \mathrm{HCN}, \mathrm{C}_{2} \mathrm{H}_{2}$, $\mathrm{C}_{2} \mathrm{H}_{6}$ suggest that $\mathrm{HCOOH}$ production is particularly linked with biomass burning. No correlation with $\mathrm{SF}_{6}$ indicates that $\mathrm{HCOOH}$ has little industrial origin. We present these correlations in Fig. 10; correlation coefficients $\left(R^{2}\right)$ are 0.69 for $\mathrm{CO}, 0.60$ for $\mathrm{HCN}, 0.72$ for $\mathrm{C}_{2} \mathrm{H}_{2}, 0.50$ for $\mathrm{C}_{2} \mathrm{H}_{6}$ and 0.01 for $\mathrm{SF}_{6}$. 

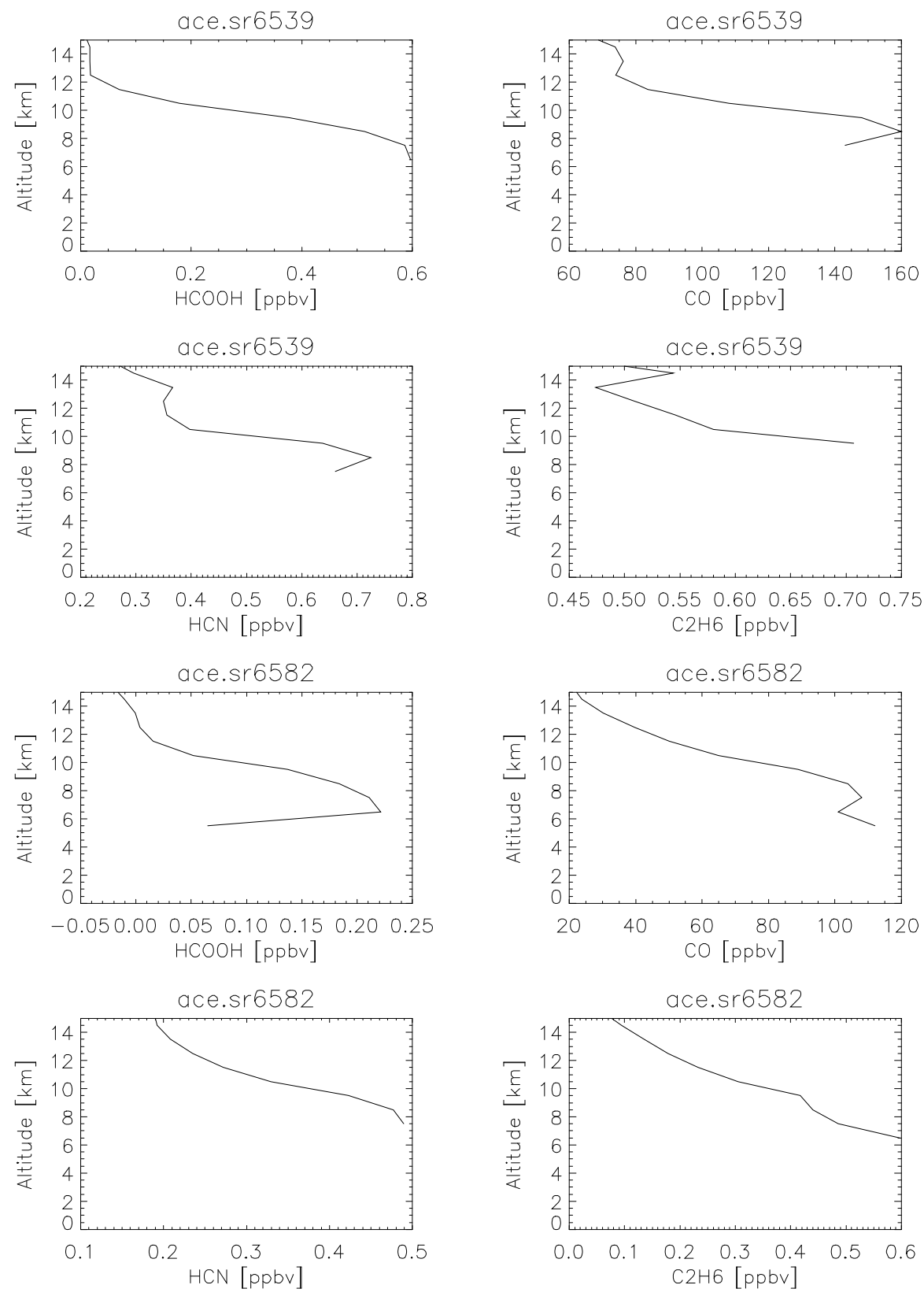

Fig. 9. $\mathrm{HCOOH}, \mathrm{CO}, \mathrm{HCN}$ and $\mathrm{C}_{2} \mathrm{H}_{6}$ profile concentrations for occultations sr6539 and sr6582. 

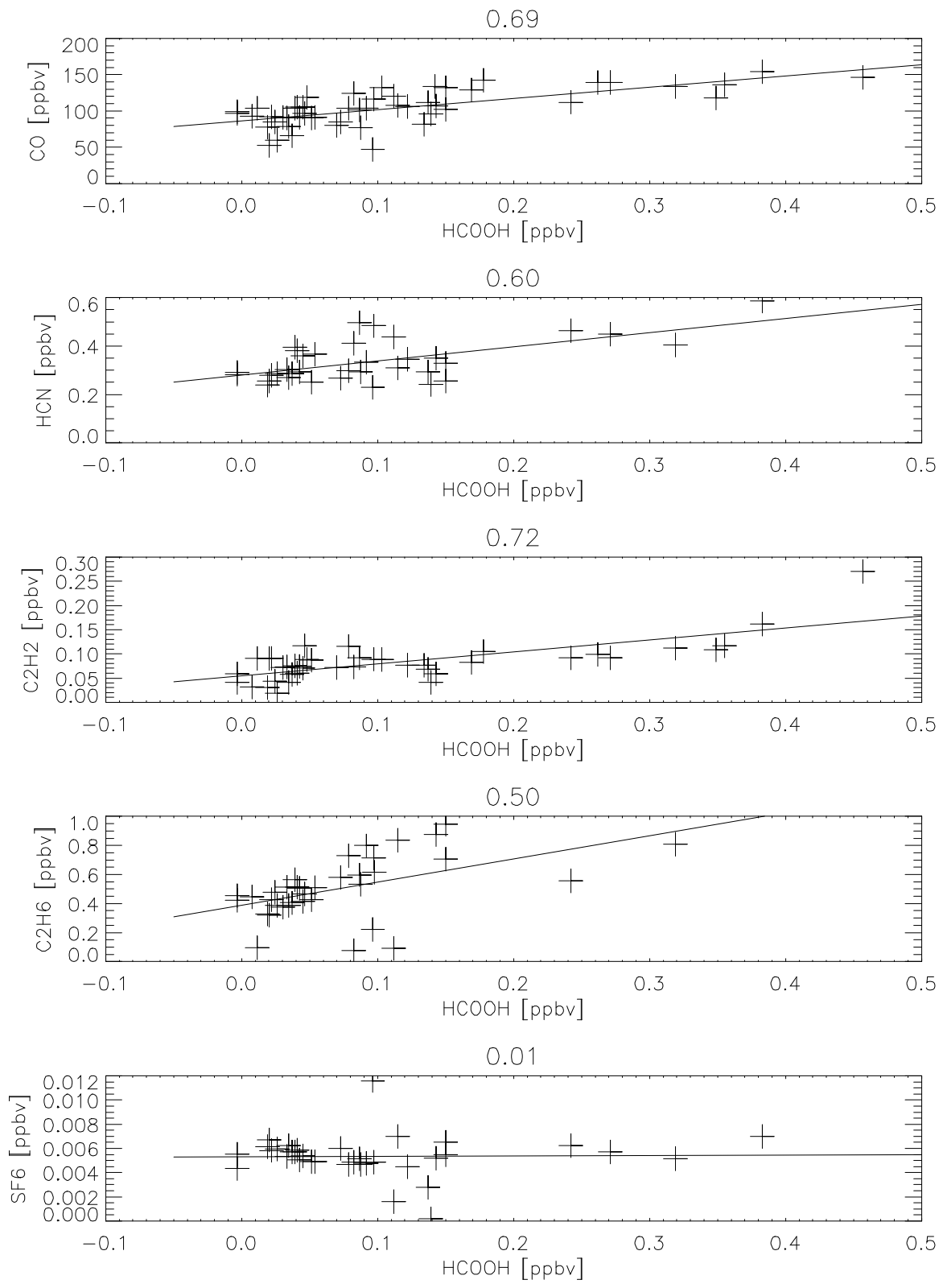

Fig. 10. Tracer-tracer concentration correlations between $\mathrm{HCOOH}$ and $\mathrm{CO}, \mathrm{HCN}, \mathrm{C}_{2} \mathrm{H}_{2}, \mathrm{C}_{2} \mathrm{H}_{6}$ and $\mathrm{SF}_{6}$.

\section{Summary and conclusion}

The first near global tropospheric distribution of formic acid $(\mathrm{HCOOH})$ has been presented using data from the ACE satellite. 8125 extravortex profiles were used for the period between February 2004 and September 2007. It has been possible to observe seasonal variations, and to relate these variations with the main sources of formic acid: biomass burning and plant growth. Values up to 590 pptv have been observed for individual profiles that are likely associated with biomass burning plumes. Strongly enhanced formic acid concentrations are seen at $5-7 \mathrm{~km}$ in the tropics at the lowest altitudes that can be observed by ACE. An emission VMR ratio of $0.0051 \pm 0.0015$ relative to $\mathrm{CO}$ was calculated for biomass burning from tropical South American forests. ACE-FTS observations are in good agreement with similar measurements made by the balloon-borne MkIV FTS. Further work has been started to compare ACE observations with the predictions of the GEOS-Chem chemical transport model. 
Acknowledgements. The ACE mission is funded primarily by the Canadian Space Agency. Funding was also provided by the UK Natural Environment Research Council (NERC), in part through the National Centre for Earth Observation (NCEO). Gonzalo González Abad thanks the Wild Fund for support. Work at the Jet Propulsion Laboratory, California Institute of Technology was done under contract with the National Aeronautics and Space Administration.

Edited by: J. B. Burkholder

\section{References}

Andreae, M. O., Talbot, R. W., Andreae, T. W., and Harris, R. C.: Formic and Acetic Acid over the Central Amazon Region, Brazil, 1, Dry Season, J. Geophys. Res., 93, 1616-1624, 1988.

Andreae, M. O. and Merlet, P.: Emission of Trace Gases and Aerosols from Biomass Burning, Global Biogeochem. Cy., 15(4), 955-966, 2001.

Atkinson, R., Baulch, D. L., Cox, R. A., Crowley, J. N., Hampson, R. F., Hynes, R. G., Jenkin, M. E., Rossi, M. J., Troe, J., and IUPAC Subcommittee: Evaluated kinetic and photochemical data for atmospheric chemistry: Volume II - gas phase reactions of organic species, Atmos. Chem. Phys., 6, 3625-4055, 2006, http://www.atmos-chem-phys.net/6/3625/2006/.

Baboukas, E. D., Kanakidou, M., and Mihalopoulos, N.: Carboxylic acids in gas and particulate phase above the Atlantic Ocean, J. Geophys. Res., 105, 14459-14471, 2000.

Bernath, P. F.: Atmospheric Chemistry Experiment (ACE): Analytical Chemistry from Orbit, Trends in Anal. Chem., 25, 647-654, 2006.

Bernath, P. F., McElroy, C. T., Abrams, M. C., Boone, C. D., Butler, M., Camy-Peyret, C., Carleer, M., Clerbaux, C., Coheur, P.-F., Colin, R., DeCola, P., DeMaziere, M., Drummond, J. R., Dufour, D., Evans, W. F. J., Fast, H., Fussen, D., Gilbert, K., Jennings, D. E., Llewellyn, E. J., Lowe, R. P., Mahieu, E., McConnell, J. C., McHugh, M., McLeod, S. D., Michaud, R., Midwinter, C., Nassar, R., Nichitiu, F., Nowlan, C., Rinsland, C. P., Rochon, Y. J., Rowlands, N., Semeniuk, K., Simon, P., Skelton, R., Sloan, J. J., Soucy, M.-A., Strong, K., Tremblay, P., Turnbull, D., Walker, K. A., Waltkty, I., Wardle, D. A., Wehrle, V., Zander, R., and Zou, J.: Atmospheric Chemistry Experiment (ACE): Mission overview, Geophys. Res. Lett., 32, L15S01, doi:10.1029/2005GL022386, 2005.

Boone, C. D., Nassar, R., Walker, K. A., Rochon, Y., McLeod, S. D., Rinsland, C. P., and Bernath, P. F.: Retrievals for the Atmospheric Chemistry Experiment Fourier Transform Spectrometer, Appl. Optics, 44, 7218-7231, 2005.

Chameides, W. L. and Davis, D. D.: Aqueous phase source of formic acid in clouds, Nature, 304, 427-429, 1983.

Coheur, P.-F., Herbin, H., Clerbaux, C., Hurtmans, D., Wespes, C., Carleer, M., Turquety, S., Rinsland, C. P., Remedios, J., Hauglustaine, D., Boone, C. D., and Bernath, P. F.: ACE-FTS observation of a young biomass burning plume: first reported measurements of $\mathrm{C}_{2} \mathrm{H}_{4}, \mathrm{C}_{3} \mathrm{H}_{6} \mathrm{O}, \mathrm{H}_{2} \mathrm{CO}$ and PAN by infrared occultation from space, Atmos. Chem. Phys., 7, 5437-5446, 2007, http://www.atmos-chem-phys.net/7/5437/2007/.

Davies, T., Cullen, M. J. P., Malcolm, A. J., Mawson, M. H., Staniforth, A., White, A. A., and Wood, N.: A new dynamical core for the Met Office's global and regional modelling of the atmosphere, Q. J. Roy. Meteorol. Soc., 131, 1759-1782, 2005.

Fishman, J., Hoell, J. M., Bendura, R. D., McNeil, R. J., and Kirchhoff, V.: NASA GTE TRACE A experiment (September October 1992): Overview, J. Geophys. Res.-Atmos., 101, 2386523879, 1996.

Goode, J. G., Yokelson, R. J., Ward, D. E., Sussot, R. A., Babbitt, R. E., Davies, M. A., and Hao, W. M.: Measurements of excess $\mathrm{O}_{3}, \mathrm{CO}_{2}, \mathrm{CO}, \mathrm{CH}_{4}, \mathrm{C}_{2} \mathrm{H}_{4}, \mathrm{C}_{2} \mathrm{H}_{2}, \mathrm{HCN}, \mathrm{NO}, \mathrm{NH}_{3}$, $\mathrm{HCOOH}, \mathrm{CH}_{3} \mathrm{COOH}, \mathrm{HCHO}$, and $\mathrm{CH}_{3} \mathrm{OH}$ in 1997 Alaskan biomass burning plumes by airborne Fourier transform infrared spectroscopy (AFTIR), J. Geophys. Res., 105, 22147-22166, 2000.

Hartmann, W. R., Santana, M., Hermoso, M., Andreae, M. O., and Sanhueza, E.: Diurnal Cycles of Formic and Acetic Acids in the Northern Part of the Guyana Shield, Venezuela, J. Atmos. Chem., 13, 63-72, 1991.

Hatakeyama, S., Bandow, H., Okuda, M., and Akimoto, H.: Reactions of $\mathrm{CH}_{2} \mathrm{OO}$ and $\mathrm{CH}_{2}\left({ }^{1} \mathrm{~A}_{1}\right)$ with $\mathrm{H}_{2} \mathrm{O}$ in the gas phase, $\mathrm{J}$. Phys. Chem., 85, 2249-2254, 1981.

Herndon, S. C., Zahniser, M. S., Nelson, Jr., D. D., Shorter, J., McManus, J. B., Jiménez, R., Warneke, C., and de Gouw, J. A.: Airborne measurements of $\mathrm{HCHO}$ and $\mathrm{HCOOH}$ during the New England Air Quality Study 2004 using a pulsed quantum cascade laser spectrometer, J. Geophys. Res., 112, D10S03, doi:10.1029/2006JD007600, 2007.

Horie, O., Neeb, P., Limbach, S., and Moortgat, G. K.: Formation of formic acid and organic peroxides in the oxonolysis of ethene with added water vapor, Geophys. Res. Lett., 21, 1523-1526, 1994.

Ito, A., Sillman, S., and Penner, J. E.: Effects of additional nonmethane volatile organic compounds, organic nitrates, and direct emissions of oxygenated organic species on global tropospheric chemistry, J. Geophys. Res., 112, D06309, doi:10.1029/2005JD006556, 2007.

Jacob, D. J.: Chemistry of OH in remote clouds and its role in the production of formic acid and peroxymonosulfate, J. Geophys. Res., 91, 9807-9826, 1986.

Jacob, D. J. and Wofsy, S. C.: Photochemistry of biogenic emissions over the Amazon forest, J. Geophys. Res., 93, 1477-1486, 1988

Kawamura, K., Ng, L. L., and Kaplan, I. R.: Determination of organic acids $(\mathrm{C} 1-\mathrm{C} 10)$ in the atmosphere, motor exhaust and engine oils, Environ. Sci. Technol., 19, 1082-1086, 1985.

Keene, W. C. and Galloway, J. N.: Organic acidity in the precipitation of North America, Atmos. Environ., 18, 2491-2497, 1984.

Keene, W. C. and Galloway, J. N.: Considerations regarding sources for formic and acetic acids in the troposphere, J. Geophys. Res., 91, 14466-14474, 1986.

Keene, W. C. and Galloway, J. N.: The biogeochemical cycling of formic and acetic acids through the troposphere: An overview of current understanding, Tellus, Ser. 40B, 332-334, 1988.

Khare, P., Kumar, N., Kumari, K. M., and Srivastava, S. S.: Atmospheric formic and acetic acids: An overview, Rev. Geophys., 37, 227-248, 1999.

Madronich, S. and Galvert, J. G.: Permutation Reactions of Organic Peroxy Radicals in the Troposphere, J. Geophys. Res., 95, 56975715, 1990.

Manney, G. L., Daffer, W. H., Zawodny, J. M., Bernath, P. F., Hoppel, K. W., Walker, K. A., et al.: Solar occultation satellite 
data and derived meteorological products: sampling issues and comparisons with Aura MLS, J. Geophys. Res., 112, D24S50, doi:10.1029/2007JD008709, 2007.

Nassar, R., Bernath, P. F., Boone, C. D., Manney, G. L., McLeod, S. D., Rinsland, C. P., Skelton, R., and Walker, K. A.: ACE-FTS measurements across the edge of the winter 2004 Arctic vortex, Geophys. Res. Lett., 32, L15S05, doi:10.1029/2005GL022671, 2005.

Perrin, A. and Vander Auwera, J.: An improved database for the $9 \mu \mathrm{m}$ region of the formic acid spectrum, J. Quant. Spectrosc. Ra., 108, 363-370, doi:10.1016/j.jqsrt.2007.05.002, 2007.

Radojevic, M. and Harrison, R. M.: Atmospheric Acidity: Sources, Consequences and Abatement, Springer, London, 1992.

Rasmussen, R. A. and Khalil, M. A. K.: Isoprene over the Amazon Basin, J. Geophys. Res., 93, 1417-1421, 1988.

Remedios, J. J., Allen, G., Waterfall, A. M., Oelhaf, H., Kleinert, A., and Moore, D. P.: Detection of organic compound signatures in infra-red, limb emission spectra observed by the MIPAS-B2 balloon instrument, Atmos. Chem. Phys., 7, 1599-1613, 2007, http://www.atmos-chem-phys.net/7/1599/2007/.

Rinsland, C. P., Mahieu, E., Zander, R., Goldman, A., Wood, S., and Chiou, L.: Free tropospheric measurements of formic acid $(\mathrm{HCOOH})$ from infrared ground-based solar absorption spectra: Retrieval approach, evidence for a seasonal cycle, and comparison with model calculations, J. Geophys. Res., 109, D18308, doi:10.1029/2004JD004917, 2004.

Rinsland, C. P., Boone, C. D., Bernath, P. F., Mahieu, E., Zander, R., Dufour, G., Clerbaux, C., Turquety, S., Chiou, L., McConnell, J. C., Neary, L., and Kaminski, J. W.: First space-based observations of formic acid (HCOOH): Atmospheric Chemistry Experiment austral spring 2004 and 2005 Southern Hemisphere tropical - mid-latitude upper tropospheric measurements, Geophys. Res. Lett., 33, L23804, doi:10.1029/2006GL027128, 2006.

Rinsland, C. P., Dufour, G., Boone, C. D., Bernath, P. F., Chiou, L., Coheur, P.-F., Turquety, S., and Clerbaux, C.: Simultaneous measurements of upper tropospheric $\mathrm{CO}, \mathrm{C}_{2} \mathrm{H}_{6}, \mathrm{HCN}, \mathrm{CH}_{3} \mathrm{Cl}, \mathrm{CH}_{4}$, $\mathrm{C}_{2} \mathrm{H}_{2}, \mathrm{CH}_{3} \mathrm{OH}, \mathrm{HCOOH}$, OCS, and $\mathrm{SF}_{6}$ mixing ratios, Global Biogeochem. Cy., 21, GB3008, doi:10.1029/2006GB002795, 2007.

Rothman, L. S., Jacquemart, D., Barbe, A., Benner, D. C., Birk, M., Brown, L. R., Carleer, M. R., Chackerian, C., Chance, K., Coudert, L. H., Dana, V., Devi, V. M., Flaud, J. M., Gamache, R. R., Goldman, A., Hartmann, J. M., Jucks, K. W., Maki, A. G., Mandin, J. Y., Massie, S. T., Orphal, J., Perrin, A., Rinsland, C. P., Smith, M. A. H., Tennyson, J., Tolchenov, R. N., Toth, R. A., Vander Auwera, J., Varanasi, P., and Wagner, G.: The HITRAN 2004 molecular spectroscopic database, J. Quant. Spectrosc. Ra., 96, 139-204, 2005.

Rothman, L. S., Gordon, I. E., Barbe, A., Benner, D. C., Bernath, P. E., Birk, M., Boudon, V., Brown, L. R., Campargue, A., Champion, J. P., Chance, K., Coudert, L. H., Dana, V., Devi, V. M., Fally, S., Flaud, J. M., Gamache, R. R., Goldman, A., Jacquemart, D., Kleiner, I., Lacome, N., Lafferty, W. J., Mandin, J. Y., Massie, S. T., Mikhailenko, S. N., Miller, C. E., Moazzen-Ahmadi, N., Naumenko, O. V., Nikitin, A. V., Orphal, J., Perevalov, V. I., Perrin, A., Predoi-Cross, A., Rinsland, C. P., Rotger, M., Simeckova, M., Smith, M. A. H., Sung, K., Tashkun, S. A., Tennyson, J., Toth, R. A., Vandaele, A. C., and Vander Auwera, J.: The HITRAN 2008 molecular spectroscopic database, J. Quant. Spectrosc. Ra., 110, 533-572, doi:10.1016/j.jqsrt.2009.02.013, 2009.

Sanhueza, E. and Andreae, M. O.: Emission of formic and acetic acids from tropical savanna soils, Geophys. Res. Lett., 18, 17071710, 1991.

Sanhueza, E., Figueroa, L., and Santana, M.: Atmospheric formic and acetic acids in Venezuela, Atmos. Environ., 30, 1861-1873, 1996.

Sen, B., Toon, G. C., Osterman, G. B., Blavier, J. -F., Margitan, J. J., Salawitch, R. J., and Yue, G. K.: Measurements of reactive nitrogen in the stratosphere, J. Geophys. Res., 103, 3571-3585, 1998.

Su, F., Calvert, J. G., and Shaw, J. H.: Mechanism of the photooxidation of gaseous formaldehyde, J. Phys. Chem., 83, 3185-3191, 1979.

Swinbank, R. and O'Neill, A.: A stratosphere-troposphere data assimilation system, Mon. Weather Rev., 122, 686-702, 1994.

Swinbank, R., Ingleby, N. B., Boorman, P. M., and Renshaw, R. J.: A 3D variational data assimilation system for the stratosphere and troposphere, Tech. Rep. 71, Met Off., Exeter, U.K.

Talbot, R. W., Beecher, K. M., Harris, R. C., and Cofer, III, W. R.: Atmospheric geochemistry of formic and acetic acids at a midlatitude temperate site, J. Geophys. Res., 93, 1638-1652, 1988.

Talbot, R. W., Andreae, M. O., Berresheim, H., Jacob, D. J., and Beecher, K. M.: Sources and sinks of formic, acetic, and pyruvic acids over central Amazonia, 2, wet season, J. Geophys. Res., 95, 16799-16811, 1990.

Talbot, R. W., Vijgen, A. S., and Harris, R. C.: Soluble species in the Arctic summer troposphere: acidic gases, aerosols, and precipitation, J. Geophys. Res., 97, 16531-16543, 1992.

Talbot, R. W., Bradshaw, J. D., Sandholm, S. T., Smyth, S., Blake, D. R., Blake, N. R., Sachse, G. W., Collins, J. E., Heikes, B. G., Anderson, B. E., Gregory, G. L., Singh, H. B., Lefer, B. L., and Bachmeier, A. S.: Chemical characteristics of continental outflow over the tropical South Atlantic Ocean from Brazil and Africa, J. Geophys. Res.-Atmos., 101, 24187-24202, 1996.

Toon, G. C.: The JPL MkIV Interferometer, Optics and Photonics News, 2, 19-21, 1991.

Vander Auwera, J., Didriche, K., Perrin, A., and Keller, F.: Absolute line intensities for formic acid and dissociation constant of the dimer, J. Chem. Phys., 126, 124311-124319, doi:10.1063/1.2712439, 2007.

Yokelson, R. J., Goode, J. G., Ward, D. E., Susott, R. A., Babbitt, R. E., Wade, D. D., Bertschi, I., Griffith, D. W. T., and Hao, W. M.: Emissions of formaldehyde, acetic acid, methanol, and other trace gases from biomass fires in North Carolina measured by airborne Fourier transform infrared spectroscopy, J. Geophys. Res., 104, 30109-30125, 1999. 